\title{
Analysis of wave energy reduction and sediment stabilization by mangroves in Gazi Bay, Kenya
}

\author{
MAINA DAVID NDIRANGU ${ }^{1}$, ROBERT MUTUGI CHIRA ${ }^{1, \boldsymbol{v}}$, VIRGINIA WANG'ONDU, ${ }^{1}$ JAMES G. KAIRO ${ }^{2}$ \\ ${ }^{1}$ School of Biological Sciences, University of Nairobi. P.O. Box 30197 (00100), Nairobi, Kenya. ^email: rchira@uonbi.ac.ke rchira@uonbi.ac.ke \\ ${ }^{2}$ Kenya Marine and Fisheries Research Institute. Mombasa, Kenya
}

Manuscript received: 5 May 2017. Revision accepted: 29 September 2017.

\begin{abstract}
Ndirangu MD, Chira RM, Wang'ondu V, Kairo JG. 2017. Wave energy reduction and sediment stabilization by mangroves in Gazi Bay, Kenya. Bonorowo Wetlands 7: 83-94. Mangrove forests provide natural protection to the coast by attenuating wave energy and stabilizing sediments. The efficiency of coastal protection is likely to decline with increased degradation and losses of mangrove forests. Nevertheless, there are few empirical studies to test these hypotheses. The study's objective was to investigate how wave energy and sediment stabilization vary with tree density in a mono-species stand of mangroves (Sonneratia alba) at Gazi Bay, Kenya. Seven belt transects were randomly selected along $900 \mathrm{~m}$ stretches of shoreline with homogenous emergent wave energy. Structural parameters, including; tree density, pneumatophores density, and basal areas, were quantified using two quadrat measuring $25 \mathrm{~m}$ by 20 $\mathrm{m}$ along each transect. Three intertidal stations with five sampling points were sampled using uniform plaster of Paris clod cards for wave energy. Sediment stability was measured using improvised sinking metal disks made from bicycle spokes, and sediment accretion was monitored by Surface Elevation Tables (SETs). All transects showed significant difference in pneumatophores density (F (2.39) $=25.15)$, tree density $\left(F_{(2.33)}=24.79\right)$, and basal area $\left(F_{(2.39)}=29.66\right)$. The wave energy sampled by tree stems between stations and the correlation of wave energy reduction against tree density/ha, pneumatophores density, and basal areas per $\mathrm{m}^{2}$ also showed a significant difference. Regression analysis showed a significant difference in the sediment stability against tree density $(\mathrm{R} 2=61 \%)$ and basal areas $(\mathrm{R} 2=72.8 \%)$, while there was no significant difference between sediment stability and pneumatophores density $(\mathrm{R} 2=47 \%)$. Regression analysis between mean sediment accretion rates against all parameters was not significant. This study will help the managers and the government on the merit of using mangroves as bio-shields in protecting coastlines against erosion and stabilizing sediment in the wake of much anticipated global changing climate and sea-level rise.
\end{abstract}

Keywords. Mangroves, Gazi Bay, Kenya, sediment stabilization, wave energy

\section{INTRODUCTION}

Mangrove forests are essential ecosystems that stabilize coastlines and protect life and property (Keryn et al., 2011). The forest extends to the intertidal areas of sheltered tropical and subtropical shores. They are confined mainly to the equatorial region between latitude $30^{\circ}$ north and $30^{\circ}$ south (Spalding et al. 2010). Globally, mangroves are estimated to cover 14-24 million ha, spread over 122 territories (Giri et al., 2010). The largest under mangrove forest is in Southeast Asia, which occupies $34-42 \%$ of global mangroves (Spalding et al., 2010).

Nigeria has the highest density of mangroves in the African continent with 4.7\%, followed by Mozambique and Madagascar with $2.3 \%$ and $2.0 \%$, respectively (Spalding et al. 2010). Considering the multiple goods and services provided by the mangrove ecosystem, there is increased effort to restore degraded mangrove forests globally (Gilman et al., 2008). Efforts to replant degraded mangrove forests were started in Kenya in the 1990s and are still ongoing (Kairo, 1995).

In Kenya, there is some information on human-induced mangrove deforestation and transformation (Abuodha and Kairo 2001). However, only little is known about the effects of degradation on ecosystem functions, such as shoreline protection. For example, at the Gazi pilot area, removing the fringing mangroves has led to the erosion of adjacent coconut plantations (Dahdouh-Guebas et al. 2000). Some $30-40 \%$ of nearshore mangroves at Gazi comprise Sonneratia alba forest, mainly adapted to frequent inundation (Neukermans et al. 2008).

In the context of climate change, mangroves build new land by accreting sediment either in-situ or exogenous (Krauss et al. 2013), thus balancing relative sea-level rise (Bell and Lovelock 2013). In the recent past, mangrove forests have provided shoreline protection (Bell and Lovelock 2013). The forest attenuates wave energy and binds sediment by its roots (Mazda et al. 1997). The previous study reported that the Caribbean coast of Belize, Honduras, and Panama (McKee et al. 2007) had shown sediment capture of $4.1 \pm 2.2 \mathrm{~cm}$ by fringing mangrove forest, which is likely to counter the global mean rates of eustatic sea-level rise of $1.5-2 \mathrm{~mm}$ year $^{-1}$ (Krauss et al. 2003)

This study measured wave attenuation by mangroves at Gazi Bay, Kenya, to establish baseline data on the protective functions of mangroves in the area. In Kenya, mangroves cover was approximately 45,590 ha and distributed along $600 \mathrm{~km}$ of the coastline by 2010 (Kirui et al. 2012). The most significant number of mangroves in Kenya is found in Lamu, 33,500 ha, Kwale district, 8375 ha, Kilifi district, 5570ha, Tana River district, 3045 ha, and 
Mombasa district, 2490 ha (Abuodha and Kairo 2001) (Figure 1)

The objectives of this research were (i) to determine the effect of trees and pneumatophores density on wave energy reduction; (ii) to assess the impact of tree and pneumatophores density on sediment stability and accretion.

\section{MATERIALS AND METHODS}

\section{Study areas}

The study was performed at Gazi Bay, approximately $60 \mathrm{~km}$ from Mombasa, Kenya, on the south coast of Kenya $\left(4^{0} 25^{\prime} \mathrm{S}\right.$ and $4^{0} 27^{\prime} \mathrm{S} ; 39^{0} 50^{\prime} \mathrm{E}$ and $\left.39^{\circ} 50^{\circ} \mathrm{E}\right)$. With a surface area of $18 \mathrm{~km}^{2}$, the Gazi Bay has an estimated mangrove cover of 615 ha (Kairo et al. 2001). The Chale peninsula shelters the bay to the east and a fringing reef to the south, where a further distance on-shore, a degraded and semipristine fringing mangrove forest occurs (Figure 1). The study site was severely degraded following deforestation in the 1970 s and early 1980s through unsustainable harvesting of industrial wood fuel. The width of the fringing mangrove forest ranges between $40-90 \mathrm{~m}$ in width and $800 \mathrm{~m}$ long. The narrow stretch of fringing mangrove forest is inundated daily during spring and neap tide (Kairo 1995).

\section{Hydrology and rainfall}

The climate of Gazi Bay resembles that of the Kenyan coast, which is influenced by both southeast and northeast monsoons. Total annual precipitation exhibits a bimodal precipitation pattern, ranging between $1000 \mathrm{~mm}$ to 1600 mm (Kairo, 1995). During spring, the tidal range in Gazi Bay falls around $\sim 4.0 \mathrm{~m}$ (Kirui et al., 2012). Long rains are under the influence of the southeast monsoon, starting in
April to August, while northeast monsoon influences the short rains

beginning from October to December. The average annual temperature is $26^{\circ} \mathrm{C}$, and the humidity is approximately 65 $80 \%$ (Bosire et al., 2003).

The Gazi Bay is an estuary of two seasonal rivers, Kidogoweni River and Mkurumuji River, which depend on rainfall experienced inland. River Mkurumuji is more prominent with a catchment of $175 \mathrm{~km}^{2}$ inland and has high flow rates; a maximum and minimum flow of $0.02 \mathrm{~m}^{3} / \mathrm{s}$ and $5.90 \mathrm{~m}^{3}$, respectively, while groundwater seepage is restricted to small parts (Kitheka et al. 2003). The hydrology of the more significant Mkurumuji river contributes positively to allochthonous nutrients together with the upcoming anthropogenic inputs from agricultural farms and mining industries during the rainy season (Kitheka et al., 2003). Human activities, mainly sugar plantations at Ramisi and Titanium mining in Kwale County, may negatively affect allochthonous sediment input due to damming upstream in both rivers.

\section{Geology}

Geologically, the Kenyan coast comprises rocks, mostly marls, and limestone, represented by sandstones, clays, conglomerates, and gravels (GOK 2009). The building industry extensively exploits these well-developed reef complexes, coral reefs, coral rubble, and sandstones (GOK 2009). Fringing reef crests dominate the Kenyan coast forming a natural barrier to the wave energy from the ocean with a shoreline comprising of reef terraces and mangroves, with a tidal flat in Gazi Bay fronting the mangroves (GOK 2010). The study site is conducted on a low shore beach that receives daily inundation (Watson inundation class 1) and has moderate wave exposure and sandy sediments. The highest spring tide is approximately $4 \mathrm{~m}$ above the datum (Kitheka et al. 2003).

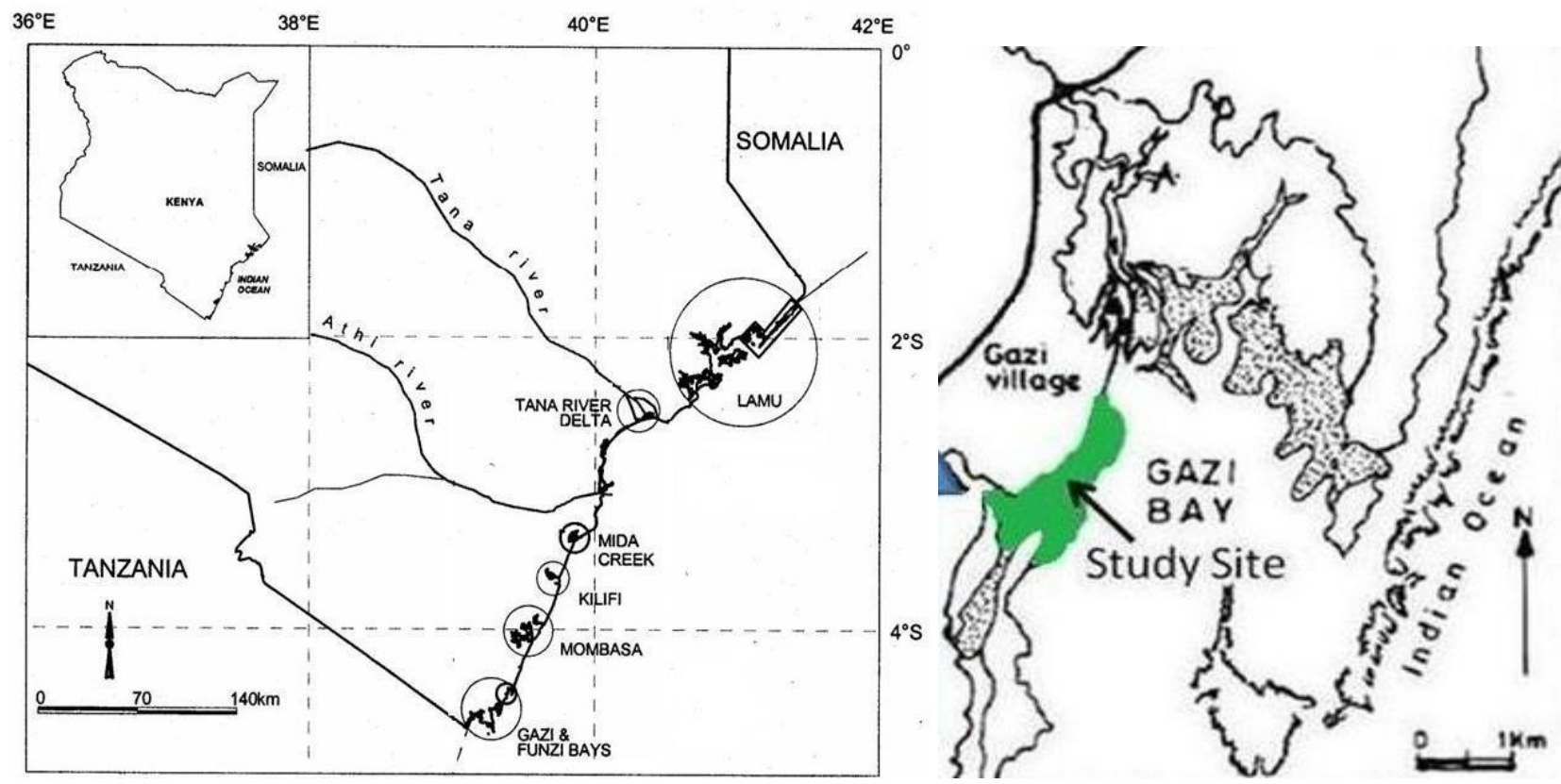

Figure 1. A map of the Kenyan Coastline showing the study site comprising of fringing mangroves in Gazi Bay (Bosire et al. 2003) 


\section{Mangroves of Gazi}

Gazi Bay possesses all the nine mangrove species described in the western Indian Ocean region. The dominant species that make up more than $70 \%$ of the formation are Ceriops tagal (Perr) C.B Robinson and Rhizophora mucronata (Lam) (Kairo et al., 2008). A typical pattern of species that occurs from the sea to the land are S. alba, R. Mucronata, Bruguiera gymnorrhiza, (L) Lam C. tagal, Avicennia marina (Forsk) Vierh, Xylocarpus granatum (Koen), Lumnitzera racemosa (Willd), Xylocarpus muluccensis (Lam) Roem and Heritiera Littoralis (Dryand) (Dahdouh-Guebas et al. 2000). The massive tidal regime controls these species. Animal species range from mollusks; to sesarmid crabs which are keystone species due to their high rate of nutrient cycling (Bosire et al. 2008). Other common species of crabs include Uca annulipes and Uca inverse (Skove et al. 2002).

Epibiotic communities of algal species encountered in seaward and landward zones include Enteromorpha ramulose, Polysiphonia sp., Hypnea sp., and Caloglossa leprieuri attached to pneumatophores of $S$. alba at different pneumatophores height. Poriferans are found growing on the pneumatophores of $S$. Alba stands with Tedania digitata vulcanis as a typical example (Crona et al. 2006).

Gazi Mangrove forests are habitats for juvenile fish, either planktivorous or benthic feeders. Common juvenile species of fish located in the fringing mangrove forest are Gerres oyena and lutjanus fulviflamma (Kirui et al., 2012). Also, the forest forms a suitable habitat for different species of snakes, residents, and migratory birds that commonly feed in nearshore environments (Kairo 1995).

\section{Social-economic activities}

Gazi Bay has a population of approximately 4825 people according to the national census of 2009, the majority being women and children. The men (90\%) are involved in artisanal fishing and mangrove cutting for sale to Mombasa and other coastal towns (Hamsa 2013). Approximately $90 \%$ of mangroves harvested are used for building houses, tannins, provision of wood fuel, ribs for boat manufacture and furniture, traditional medicine (Dahdouh-Guebas et al. 2000). Meanwhile, women are mostly engaged in small businesses and weaving makuti (roof thatches made from coconut fronds) farming (Dahdouh-Guebas et al., 2000). Mangroves have also been used extensively by undergraduate and postgraduate research students from various disciplines to address various research questions (Kairo et al., 2009).

Recently, Mikoko Pamoja, a community-based mangrove conservation initiative, has started mangrove restoration and protection in the bay. Together with KMFRI and Universities in the UK, their attempt for mangrove restoration and preservation is made by selling carbon credits in the voluntary carbon market (Hamsa 2013).

\section{Project design}

Change in wave energy was measured across seven belt transects selected randomly and perpendicular to the shoreline in a mono-species of fringing of Sonneratia forest (Figure 2). The seven transects had varying tree and pneumatophores densities and were denoted with letters K, L, M, N, O, and P. Among the seven transects, transect Q had no mangrove cover and was selected as a control. The belt transect was set short from river Mkurumuji, heading north towards the Bay. This selection was made to incorporate vegetation structural differences of fringing mangroves.

The positioning of transects was done in areas where the bandwidth of the mangrove trees stretch was $\geq 80 \mathrm{~m}$. This positioning was made because the bandwidth of the mangrove forest was not uniform at the study site. It was the most extensive stretch of mangrove cover that existed and allowed a sufficient number of transects.

\section{Sampling design}

The density of mangrove trees was quantified in seven; $80 \mathrm{~m}$ long belt transects by utilizing two plots, each measuring $25 \mathrm{~m}$ long and $20 \mathrm{~m}$ width. The plots were systematically selected along each transect set perpendicular to the shoreline. The first plot was established $20 \mathrm{~m}$ from the lowest mangrove tree on the seaward side, while the second plot was set $5 \mathrm{~m}$ from the first plot toward the landward side. Pneumatophores density was determined by systematically selecting five quadrants, each measuring $1 \mathrm{~m}$ by $1 \mathrm{~m}$ nested in each of the more prominent plots of $25 \mathrm{~m}$ by $20 \mathrm{~m}$. At each corner, the four plots of $1 \mathrm{~m}$ by $1 \mathrm{~m}$ were set, one at the middle of each of the two plots. A total of ten plots per transect were selected to estimate pneumatophore density per transect. A total of 12 plots were selected to calculate mangrove trees and pneumatophores density, respectively, at the study site.

Wave energy was measured at three stations marked A, $\mathrm{B}$, and $\mathrm{C}$ across seven transects set perpendicular to the shoreline. A total of 21 stations were characterized in the study area. Station A was $\sim 20 \mathrm{~m}$ from the last mangrove trees on the seaward side, which measured incident wave energy before mangrove influence; station $B$ was $50 \mathrm{~m}$ from station A while station $\mathrm{C}$ was $80 \mathrm{~m}$ from station A. Station $\mathrm{B}$, and $\mathrm{C}$ measured incident wave energy passing through the mangrove forest. Each station was marked with five wooden poles of $10 \mathrm{~cm}$ girth, $1.5 \mathrm{~m}$ high, driven $70 \mathrm{~cm}$ into the ground.

Paris clods were used to measure wave energy. The clods were prepared by mixing $11.4 \mathrm{ml}$ of freshwater with 14.3g plaster of Paris powder manufactured by LAFARGE PRESTIA ( $w w w$.lafargeprestia.fr) (Figure 3). The powder was slowly added to water and stirred with a spoon. The slurry was poured into plastic ice cube trays. The trays were tapped several times vigorously to dislodge air bubbles and allowed to harden for between 20-30 minutes before removing them. The cards were oven-dried for 48 hours at 40 degrees centigrade following this step. The final weight of the clod after exposure to the field was determined by subtracting the total weight of the clod plus the plastic plate and the silicon cement before exposure. The basic assumption was that the weight of the plastic and that of the silicon cement remained constant and did not change due to corrosion by seawater. 


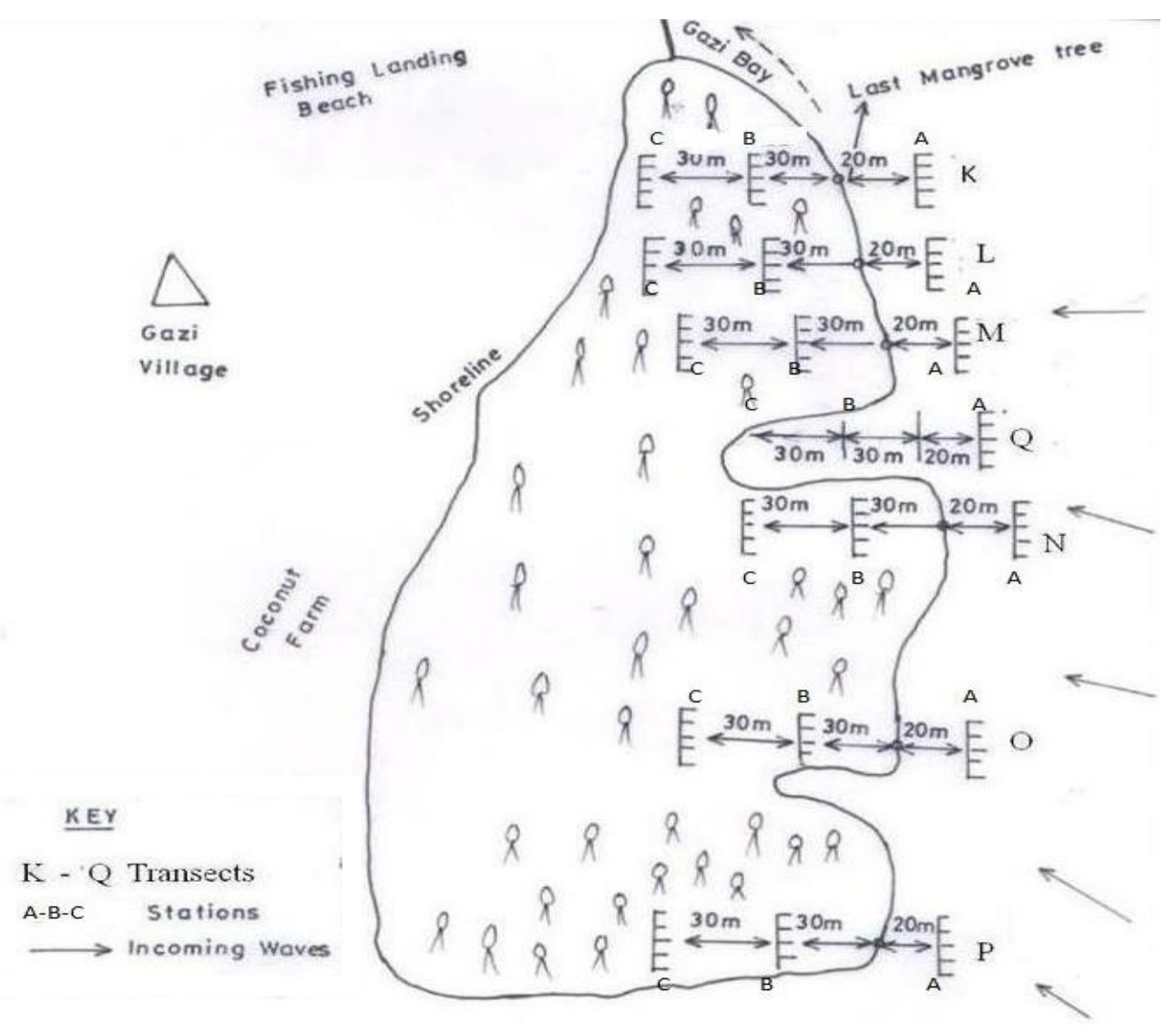

Figure 2. Schematic diagram showing the relative position of stations in each transect at the study site (not drawn to scale)

The clod cards were then sanded at the bottom to attain a uniform weight of $14 \pm 1.5 \mathrm{~g}$ within a batch. They were glued to a $3 \mathrm{~cm} \times 8 \mathrm{~cm}$ plastic plate with silicone cement (No-Nonsense Ltd.BA 228RT). These cards were taken to the field and mounted on the poles at $15 \mathrm{~cm}$ and $50 \mathrm{~cm}$ from the substrate surface, respectively, as shown in Figure 4. The clod cards mounted at $15 \mathrm{~cm}$ measured wave energy reduction by pneumatophores, while the clod cards mounted at $50 \mathrm{~cm}$ measured wave energy reduction by mangrove tree stems.

Soil samples were collected at 10 points extending the three stations for each transect: station $\mathrm{A}$ on the seaward side, station $\mathrm{B}$ in the middle of mangrove forest, and $\mathrm{C}$ on the landward side. The soil samples were obtained using a cover at approximately $5 \mathrm{~cm}$ depth. The points at which the samples were collected cover a distance of $25 \mathrm{~m}$ and each station and are separated 5 corerm away from each other. The ten samples for each station were pooled in a onelabeled plastic bag and mixed thoroughly to make one composite.

The sediment stability was measured using cheap and inexpensive bicycle spokes fitted with metal disks at the three stations in the same transects set perpendicular to the shoreline where wave energy was determined. As many as ten replicate points, which were $2.5 \mathrm{~m}$ apart, were systematically selected, covering a $25 \mathrm{~m}$ along with each station. The spokes were fitted with the metal disks weighing $2.8 \mathrm{~g}$ and $1.7 \mathrm{~cm}$ in diameter and inserted approximately $5 \mathrm{~cm}$ bicycle in the sediment. The spokes held the metal disks and left them at the substrate surface so that unstable sediment could cover them as sediment settles down during the alternating high and low tide regimes. A total of 30 spokes per transect were used in six transects with contrasting mangrove tree densities. One transects without tree cover was established perpendicular to the shore as a control. The bicycle spokes and the metal disc were inexpensive for estimating sediment stability because the materials used were cheap and locally available. We suggest that the metal disk was denser than seawater and sunk during high tide. Second, the dimension of the spoke, such as thickness, did not modify the site by reducing water velocity, thus facilitating sediment to settle. Furthermore, all spokes and metal discs at station A before the mangroves on the seaward side were used to control all transects.

Measurement of sediment accretion was done using $3 \mathrm{~m}$ long and $1 \mathrm{~cm}$ diameter stainless steel rods. Two metal rods were set $50 \mathrm{~cm}$ apart and driven $280 \mathrm{~cm}$ into the sediment at station $\mathrm{B}$, which was almost in the middle of the transect. A portion of $20 \mathrm{~cm} \pm 0.1 \mathrm{~cm}$ of each rod was left projecting perpendicular above the substrate surface. Leveling was done using the spirit level to ensure both steel rods were at the same height. Thus, sediment accretion was estimated at six sites in six transects set perpendicular to the shoreline. 
The use of steel rods has the advantage of determining accretion and erosion and gives information about subsurface processes down to the maximum level at which the pins are driven. The use of rods in the surface elevation tables (R-SET) is advantageous since it is cheap regarding cost, high-precision, simple, and is accessible to economically developing countries with coastal wetlands. In this experiment, a wooden board $4.2 \mathrm{~cm} \times 2.2 \mathrm{~cm}$ and 50 $\mathrm{cm}$ long smoothened flat, and the square was used to determine sediment accretion. The wooden board was placed on the two rods projecting above the substrate. Ten replicate points were marked along the entire length of the wooden board. The wooden board was set on the two rods projecting on the substrate surface to determine surface elevation changes at each transect.

\section{Data collection methods}

Within the two plots measuring $25 \mathrm{~m}$ by $20 \mathrm{~m}$ along each transect, diameter at breast height (DBH) of mangrove tree stem was measured at D130 or diameters at $1.3 \mathrm{~m}$ above the ground (Cintron and Schaeffer-Novelli, 1984). All mangrove tree stems in diameter D130 $\geq 2.5 \mathrm{~m}$ were measured and recorded. Stand density per hectare for each transect was calculated using the relation. $\mathbf{D i}=\mathbf{n i} / \mathbf{A i}$. Where; $\mathbf{D}_{\mathbf{i}}$ is the density for species $\mathbf{i}, \mathbf{n}_{\mathbf{i}}$ is the total number of individuals counted for species, and $\mathbf{A}_{\mathbf{i}}$ is the total area sampled (Brower and Carl., 1990). Basal areas were calculated using the formula; $\mathrm{BA}=0.00007854 \times \mathrm{DBH} 2$ (where DBH is the diameter at breast height). Ten pneumatophores were selected randomly in ten quadrats per transect measuring $1 \mathrm{~m} \times 1 \mathrm{~m}$. Their height and diameter at $1 / 2$ heights were measured using a standard ruler and Vanier calipers, respectively. The density of the pneumatophores was calculated per meter square in each transect and recorded.
Wave energy was sampled twice covering northeast monsoon season by exposing clod cards to wave action for 48 hours on the 8th to 10th October 2012 during spring. A replicate sampling of wave energy was taken during neap tide on the 16th -18 th November 2012. During the southeast monsoon season, wave energy sampling was done by exposing clod cards for 48 hours on the 1 st to 3 rd March 2013 during spring tide. A replicate sampling of wave energy was retaken on the 25th to 27th May 2013. During the four sampling regimes, clod cards were mounted and retrieved during low water.

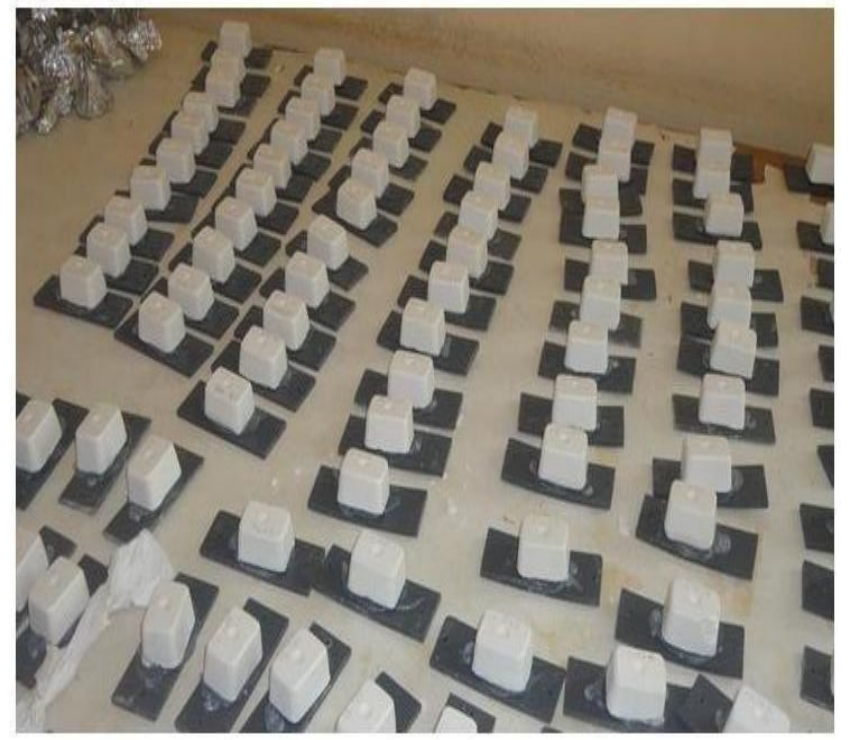

Figure 3. Oven-dried clod cards attached to plastic plates with silicon cement before exposure in the field (Photo by MDN)

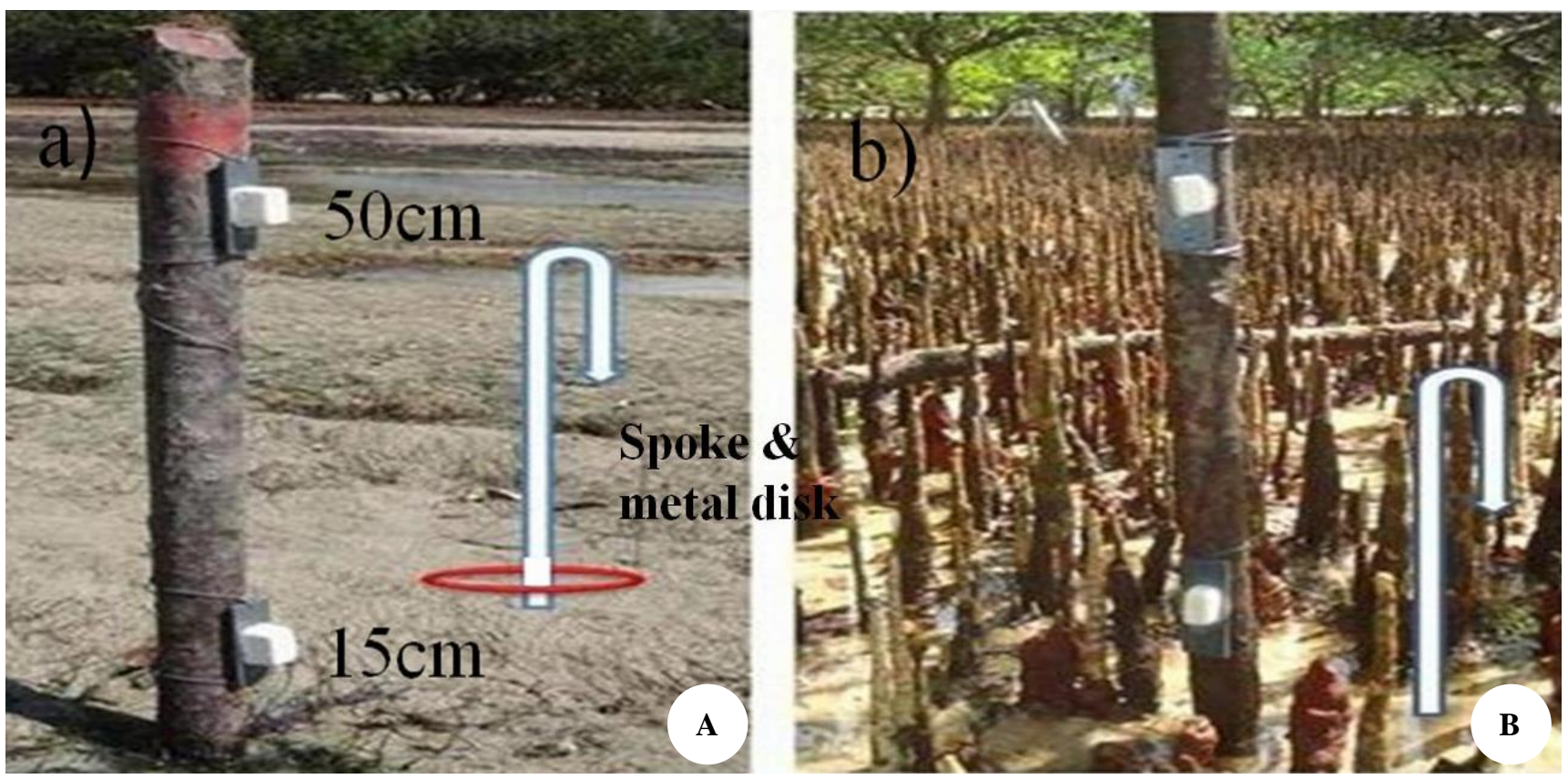

Figure 4. A setup showing (A) station A on the seaward side; (B) station B in the mangrove; with upper (50 cm) and lower (15 cm) clod card, a bicycle spoke, and a metal disk (Photo by MDN) 


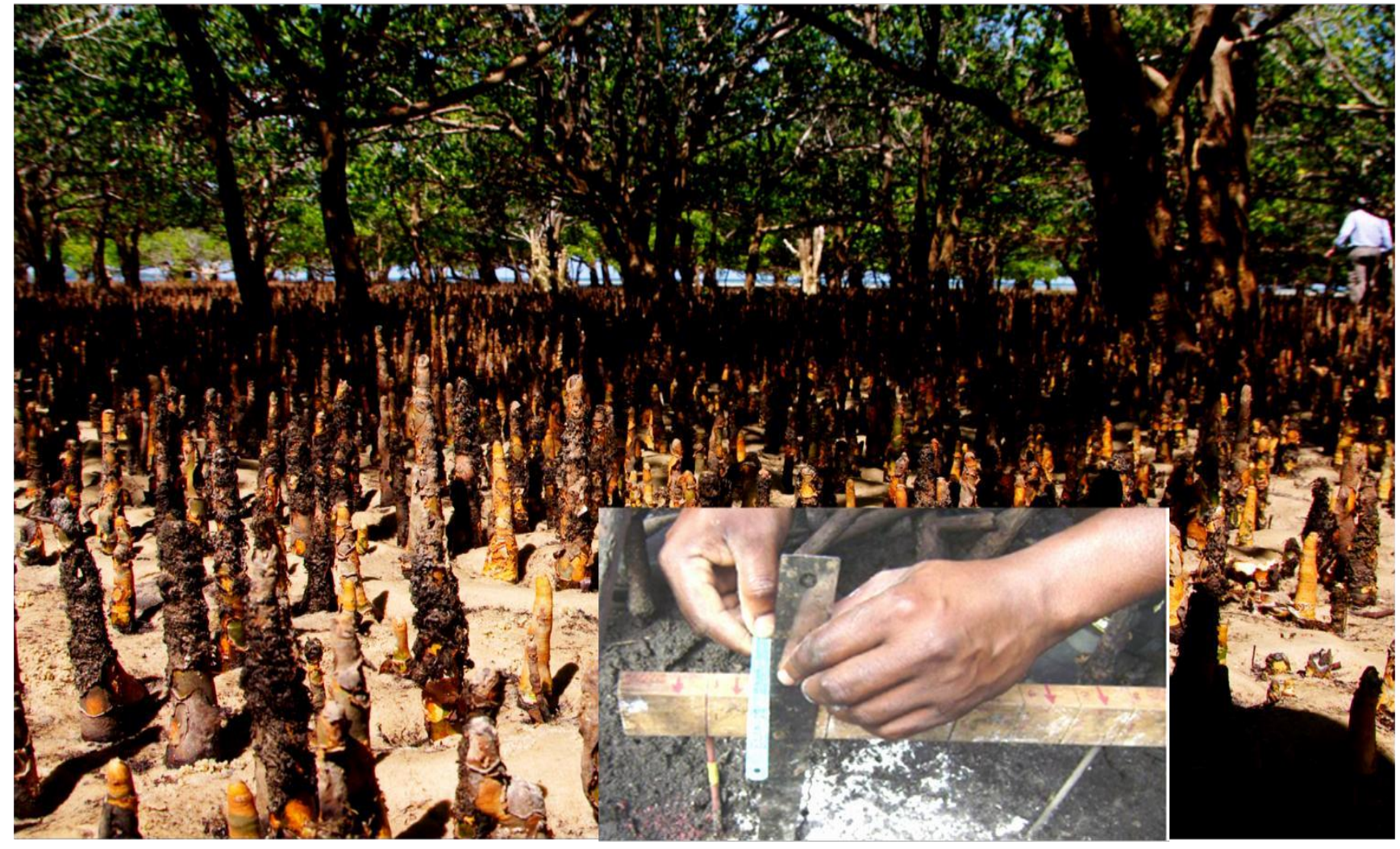

Figure 5. Surface elevation station measuring sediment accretion in a Sonneratia alba forest at Gazi Bay, Kenya (Photo by MDN)

The underlying assumptions were; First, station A would be impacted more by high water velocity in all transects due to the absence of mangrove forest structures, thus experiencing high dissolution rates of clod cards. Secondly, lower clod cards sampled the energy absorbed by pneumatophores, while the upper clod card sampled the hydrological energy consumed by the tree stems and pneumatophores. Also, the magnitude of the tide could not change within the same tide cycle during clod card exposure.

Data collection of the soil samples was done in the laboratory. After drying, the samples were weighed; ovendried at $80^{\circ} \mathrm{C}$ for 24 hours to determine the percentage moisture content. A sub-sample of $25 \mathrm{~g}$ from each station was accurately weighed from the dried soil samples for grain size analysis. The second set of samples weighing 25 $\mathrm{g}$ was labeled and preserved for organic matter analysis.

The sediment $(25 \mathrm{~g})$ was put in a labeled beaker and treated with $(6.2 \mathrm{~g} / 1$ dilution) of $250 \mathrm{ml}$ water and $10 \mathrm{ml}$ aqueous sodium hexametaphosphate ((NaPO3)6). The solutions were stirred for 10 minutes, left for four hours, and then stirred for 10 more minutes. The content of the beaker was flushed through a $63 \mu \mathrm{m}$ sieve with fresh water until no further silt was lost. The wet sediment was carefully flushed into a pre-weighed foil boat and ovendried at $800 \mathrm{C}$ for 12 hours. Next, the dry content was weighed to determine the weight of silt. The dry sediment was then flushed through a $500 \mu \mathrm{m}$ sieve. The sediment grain size $>500 \mu \mathrm{m}$ was weighed and recorded and used to calculate the weight of the $63-500 \mu \mathrm{m}$ fraction. From the oven-dried preserved sample of $25 \mathrm{~g}$, a sub-sample of $10 \mathrm{~g}$ was weighed and put in pre-weighed aluminum crucibles and set in a muffle furnace for combustion at $4400 \mathrm{C}$ for 6 hours. The procedure was followed by cooling the samples in a desiccator and weighing them to determine the organic matter in the sediment.

The sediment stability was monitored by estimating the depth at which the metal disks sunk in the sediment. Every month, the depth of sinking metal disks was estimated using a standard ruler during low tide. New spokes and metal disks were reset for the presiding month to avoid confounding due to changes in the disks' mass due to the corrosive nature of seawater. Sediment accretion was estimated using a standard ruler by measuring the height from the substrate to the wooden board placed on the two rods. Ten replicate measurements were taken and recorded once each month for all the six transects from the ten points marked on the wooden board (Figure 5). The measurements were taken for 8 months, covering 240 days

\section{Data analysis methods}

Data were analyzed using MINITAB 14.0 software package. One-way analysis of variance (ANOVA) was performed to test the variations in three parameters: tree density, pneumatophores density, and basal areas between transects. The same data analysis was also performed to examine how wave energy varied between the three stations in different transects with varying tree and 
pneumatophores densities. Pearson's correlation analysis was carried out to investigate the significance of the forest structure, namely, tree density, pneumatophores density, and basal areas against wave energy.

Correlation analysis was conducted to test for significant differences between silt, fine sand, coarse sand, and organic matter against tree and pneumatophore density. ANOVA was used to test for variation in sediment stability during the two sampling regimes and differences between stations in different transects. Regression analysis was carried out to check for sediment stability and sediment accretion against tree density/ha and pneumatophores density $\mathrm{m}^{2}$.

\section{RESULTS AND DISCUSSION}

\section{Forest structure at the study site}

Transect $M$ had the highest pneumatophores density $174 \pm 21.1$ Ind. $/ \mathrm{m}^{2}$. Tree density and basal areas were highest in transect L, $690 \pm 330 \mathrm{Ind} / \mathrm{ha}$, and $11.5 \pm 2.6 / \mathrm{m}^{2}$, respectively, whereas transect $\mathrm{O}$ had the lowest structural attributes in the study site. All transects showed significant difference in tree density $\left(\mathrm{F}_{(2,33)}=24.79, \mathrm{p}=0.000\right)$ pneumatophores density $(\mathrm{F}(2,39)=25.15, \mathrm{p}=0.000)$, and basal area $\left(\mathrm{F}_{(2,39)}=29.66, \mathrm{p}=0.01\right)$. Table 1 summarizes the structural parameters of mangrove forests in the study area.

\section{Effect of tree and pneumatophores density on wave energy reduction}

Wave energy sampled by stems in all station A on the seaward side before the mangrove influence had the highest mean in wave energy expressing $81.4 \pm 5.1 \%$ (SE), reducing gradually from station $\mathrm{B}(73.1 \pm 4.9 \%(\mathrm{SE}))$ to $\mathrm{C}$ $(65.5 \pm 5.5 \%(\mathrm{SE}))$. Transect $\mathrm{Q}$ with no mangrove cover had the highest mean in wave energy sampled by tree stems, expressing a mean of $84.3 \pm 1.7 \%$ (SE) in station A, $81.5 \pm 1.4 \%$, and $77.9 \pm 2.0 \%(\mathrm{SE})$ in station $\mathrm{B}$ and $\mathrm{C}$, respectively. The mean wave energy sampled by mangrove stems was $73.4 \pm 4.8$, while the mean of the control station $\mathrm{Q}$ had $81.2 \pm 2.9$. The mean wave energy expressed in the control denoted with letter Q (without mangrove trees) was higher by $7.8 \%$ than the mean wave energy reduction in the six transects with mangrove tree cover. Table 2 summarized the results for wave energy reduction along with stations $\mathrm{A}, \mathrm{B}$, and $\mathrm{C}$ in all transects sampled at $50 \mathrm{~cm}$ by tree stems and the mean of the three stations per transect.

Wave energy sampled at $15 \mathrm{~cm}$, which expressed energy reduction by pneumatophores in all station A on the seaward side before mangrove influence, had the highest mean of wave energy expressing $84.7 \pm 2.7 \%$ (SE). Results for wave energy reduction across stations $\mathrm{A}, \mathrm{B}$, and $\mathrm{C}$ in all transects sampled at $15 \mathrm{~cm}$ by pneumatophores and the mean of the three stations per transect are shown in (Table 3).

The energy from stations $\mathrm{B}$ to $\mathrm{C}$ has gradually reduced at an average of $77.5 \pm 2.8$ and $73.5 \pm 2.8 \%$ (SE), respectively. Transect Q (Control) without pneumatophores cover had the highest mean in wave energy in station A, expressing $86.4 \pm 2.5$, while station B and C expressed 84.3 \pm 1.5 and $81.3 \pm 1.6 \%(\mathrm{SE})$, respectively. On average, wave energy reduced by pneumatophores in the six transects with varying pneumatophore cover was $79.0 \pm$ 1.9. Meanwhile, the mean wave energy measured at the three stations (A, B, and C) in transect without pneumatophore cover (control transect) had 84.0 \pm 2.9 . Therefore, the difference in wave energy reduction in areas covered by pneumatophores and those without (the control transects) was 5\%. ANOVA showed a significant difference in the wave energy reduction by pneumatophores between stations A, without pneumatophores cover, and stations $\mathrm{B}$ and $\mathrm{C}$ with pneumatophores cover $\left(\mathrm{F}_{(2.18)}=17.05, \mathrm{p}=0.000\right)$.

Total energy reduced by mangrove trees reached $7.8 \%$, while the energy reduced by pneumatophores was $5.0 \%$. The entire wave energy reduced by both tree density and pneumatophore density was $12.8 \%$.

To get the relation between wave energy change across the mangrove forest and better understand the effect of tree density on the wave energy, a plot of wave energy on the $\mathrm{Y}$-axis and transects with different tree densities on the $\mathrm{X}$ axis was plotted. The wave energy reduction measured at $50 \mathrm{~cm}$ above the substrate (energy reduction by mangrove tree stems) is shown in Figure 7. The result showed wave energy decreasing with increasing tree density.

Table 1. Mean values \pm SD of structural characteristics of the mangrove forest at Gazi Bay, Kenya

\begin{tabular}{lcccc}
\hline Transect & $\begin{array}{c}\text { Tree } \\
\text { height } \\
(\mathbf{m})\end{array}$ & $\begin{array}{c}\text { Basal } \\
\text { area (ha) }\end{array}$ & $\begin{array}{c}\text { Tree Density } \\
\text { (stems/ha) }\end{array}$ & $\begin{array}{c}\text { Pneumatophores } \\
\text { Density }\left(\mathbf{m}^{\mathbf{2}}\right)\end{array}$ \\
\hline $\mathrm{K}$ & $6.5 \pm 0.7$ & $8.1 \pm 7.6$ & $320 \pm 300$ & $57.2 \pm 19.8$ \\
$\mathrm{~L}$ & $5.4 \pm 0.2$ & $11.5 \pm 2.6$ & $690 \pm 330$ & $146.3 \pm 1.3$ \\
$\mathrm{M}$ & $6.1 \pm 0.3$ & $18.1 \pm 1.3$ & $580 \pm 240$ & $174.9 \pm 21.1$ \\
$\mathrm{~N}$ & $5.5 \pm 0.1$ & $8 \pm 1.3$ & $496 \pm 208$ & $88.6 \pm 19.8$ \\
$\mathrm{O}$ & $4.2 \pm 0.5$ & $1.2 \pm 0.6$ & $92 \pm 28$ & $38.4 \pm 24.4$ \\
$\mathrm{P}$ & $5.2 \pm 0.3$ & $6.8 \pm 3.2$ & $510 \pm 50$ & $173.7 \pm 37.9$ \\
Mean & $5.5 \pm 0.8$ & $7.3 \pm 3.4$ & $448 \pm 212.3$ & $113.2 \pm 59.8$ \\
\hline
\end{tabular}

Table 2. Mean values $\pm \mathrm{SE}$ of wave energy reduction by mangrove stems (sampled at $50 \mathrm{~cm}$ in the three stations; A (Open areas in the seaward side) and station $\mathrm{B}$ and $\mathrm{C}$ in the mangrove

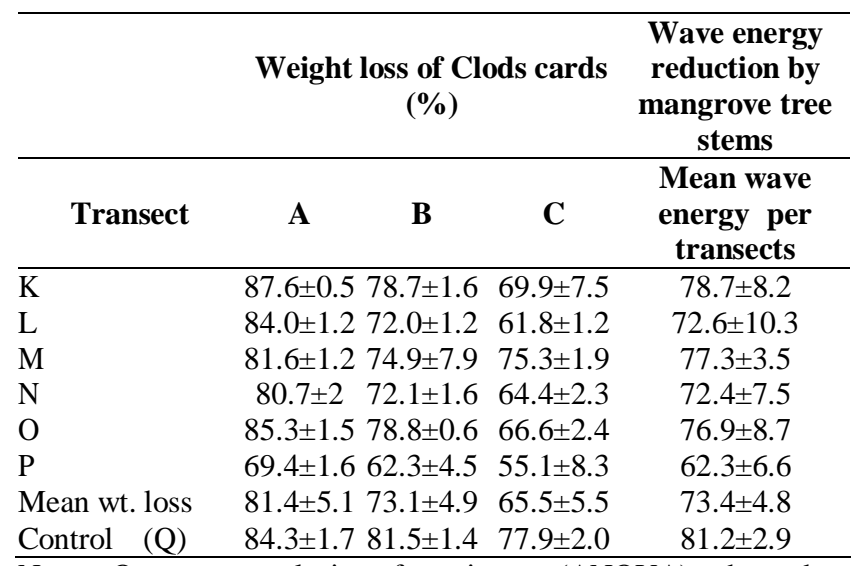

Note: One-way analysis of variance (ANOVA) showed a significant difference in wave energy sampled by tree stems between stations $\mathrm{A}, \mathrm{B}$, and $\mathrm{C}\left(\mathrm{F}_{(2,18)}=10.92, \mathrm{p}=0.001\right)$. 
The plot for hydrological energy sampled at $15 \mathrm{~cm}$ above (energy reduction by pneumatophores density) against pneumatophores density in the seven transects showed the same trend as the energy reduction sampled by tree density where wave energy-reduced with increasing pneumatophore density (Figure 8).

The results for Pearson's correlation of wave energy showed significant negative correlation coefficient for the three forest structures namely; Wave energy against tree density/ha $\left(\mathrm{r}^{2}=-0.594, \mathrm{p}=0.000\right)$, wave energy against pneumatophores density $/ \mathrm{m}^{2},\left(\mathrm{r}^{2}=-0.794, \mathrm{p}=0.0000\right)$ and wave energy against Basal area $\left(\mathrm{m}^{2}\right)\left(\mathrm{r}^{2}=-0.451, \mathrm{p}=0.000\right)$.

\section{Sediment grain size and organic matter distribution}

The analysis of grain size showed a higher percentage of silt in transect $\mathrm{M}, \mathrm{K}$, and $\mathrm{L}$ expressing $15.2 \pm 5.8 \%$, $15.0 \pm 2.2 \%$, and $8.8 \pm 21.2 \%$ (SE) while coarse sand was highest in transects $\mathrm{P}, \mathrm{O}$, and $\mathrm{N}$ expressing $39.7 \pm 0.1,18.1$ \pm 0.5 and $12.8 \pm 0.9$ (SE) respectively. All transects expressed mean fine sand as the highest proportion of sediment by $79.5 \pm 4.7 \%$ (SE). Coarse sand was least frequent in all transects except transect $\mathrm{P}$, which had a mean of $39.7 \pm 0.1 \%$. Transect $Q$ displayed the highest percentage of fine sand with $93.1 \pm 0.4 \%$ (SE).

Pearson product-moment correlation showed no significant difference between mean silt and tree density $\left(\mathrm{r}^{2}\right.$ $=0.530, p=0.221)$, fine sand and tree density $\left(r^{2}=-0.307\right.$, $\mathrm{p}=0.503)$ and coarse sand and tree density $\left(\mathrm{r}^{2}=0.083, \mathrm{p}=\right.$ 0.860 ) among transect in the study site. Correlation between mean silt and pneumatophores density $\left(r^{2}=0.484\right.$, $\mathrm{p}=0.271)$, fine sand and pneumatophores density $\left(r^{2}=-\right.$ $0.580, \mathrm{p}=0.171)$ and coarse sand $\left(\mathrm{r}^{2}=0.358, \mathrm{p}=0.431\right)$ was also not significant in all transect.

Organic matter distribution was highest in transect $\mathrm{K}$, $\mathrm{M}$, and $\mathrm{N}$ expressing $2.1 \pm 0.5,1.9 \pm 0.4$, and $1.6 \pm 0.5$ (SE) respectively, while the control transects $(\mathrm{Q})$ with no mangrove cover expressed the lowest percentage of $0.8 \pm$ 0.1 (SE). No significant correlation of organic matter between tree density/ha $(r=0.521, p=0.230)$ and also in pneumatophores density $/ \mathrm{m}^{2}(\mathrm{r}=0.367, \mathrm{p}=0.419)$. Results for sediment grain sizes and organic matter content during the study period are summarized in (Table 4).

\section{Effect of tree and pneumatophores density on sediment stability and accretion}

Mean sinking depths of metal disks in the entire sampling period were pooled per stations $\mathrm{A}, \mathrm{B}$, and $\mathrm{C}$ covering both southeast and northeast monsoon seasons. All stations before the mangrove influence on the seaward side (station A) displayed the highest means of sinking depths of metal disks of $14.6 \pm 3.1 \mathrm{~mm}(\mathrm{SE})$. The depth reduced gradually from station $B$ to $C$, which attained a sinking depth of $8.2 \pm 2.7 \mathrm{~mm}(\mathrm{SE})$ and $7.4 \pm 3.5 \mathrm{~mm}(\mathrm{SE})$, respectively. In contrast, near river Mkurumuji, transect $\mathrm{P}$ recorded a slightly high sinking depth in station $\mathrm{C}$ on the landward side with $7.35 \pm 0.8$ (SE) than stations B and C, which had similar values of $5.78 \pm 0.6(\mathrm{SE})$. On the other hand, Transect $\mathrm{Q}$ with no mangrove cover registered the highest mean depth of $23.2 \pm 2.3 \mathrm{~mm}(\mathrm{SE})$ in the three stations. Unlike most stations in another transect with varying tree cover, station $\mathrm{A}$ in the open area (control transect Q) had the least depth of $19.9 \pm 2.4$ (SE) compared with stations $B$ and $C$, which recorded $21.9 \pm 2.2$ and 27.7 \pm 2.9 (SE) respectively. Transect $M$ had the least mean depth of $2.9 \pm 1.11 .6$ (SE) in all transects.

ANOVA showed a significant difference in sinking depth of metal disks between stations $\mathrm{A}$ B and $\mathrm{C}$ in transects with varying mangrove tree cover $\left(\mathrm{F}_{(2,15)}=4.57\right.$, $\mathrm{p}=0.028)$. The results for sediment stability comparing different stations along seven transects are shown in (Figure 9).

Table 3. Mean values \pm SE of wave energy reduction by pneumatophores in the three stations; A (Open areas on the seaward side) and station $\mathrm{B}$ and $\mathrm{C}$ in the mangrove

\begin{tabular}{|c|c|c|c|c|}
\hline & \multicolumn{3}{|c|}{ Weight of Clods cards (\%) } & $\begin{array}{c}\text { Wave energy } \\
\text { reduction by } \\
\text { pneumatophores }\end{array}$ \\
\hline Transect & $\mathbf{A}$ & B & C & $\begin{array}{l}\text { Mean wave energy } \\
\text { reduction per } \\
\text { transects }\end{array}$ \\
\hline K & $85.5 \pm 0.6$ & $75.7 \pm 1.8$ & $68.3 \pm 1.2$ & $76.5 \pm 9.8$ \\
\hline $\mathrm{L}$ & $80.3 \pm 2$ & $72.9 \pm 1.9$ & $71.2 \pm 1.8$ & $74.8 \pm 5.5$ \\
\hline $\mathrm{M}$ & $88.5 \pm 0.9$ & $82.3 \pm 1.2$ & $75.4 \pm 1.6$ & $82.1 \pm 7.4$ \\
\hline $\mathrm{N}$ & $85.5 \pm 2$ & $75.5 \pm 1.4$ & $73.5 \pm 1.6$ & $78.2 \pm 7.3$ \\
\hline $\mathrm{O}$ & $87.8 \pm 1.6$ & $80.9 \pm 0.5$ & $74.2 \pm 0.9$ & $80.9 \pm 7.7$ \\
\hline $\mathrm{P}$ & $81.0 \pm 8.8$ & $77.8 \pm 7.3$ & $78.3 \pm 2.8$ & $79.0 \pm 1.9$ \\
\hline Mean wave energy & $84.7 \pm 2.7$ & $77.5 \pm 2.8$ & $73.5 \pm 2.8$ & $78.6 \pm 2.3$ \\
\hline Control & $86.4 \pm 2.5$ & $84.3 \pm 1.5$ & $81.3 \pm 1.6$ & $84.0 \pm 2.9$ \\
\hline
\end{tabular}

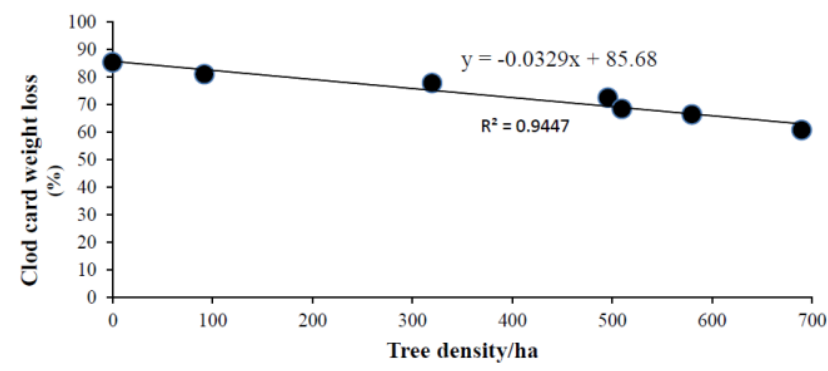

Figure 7. Linear relationship between wave energy against tree density/ha in seven transects

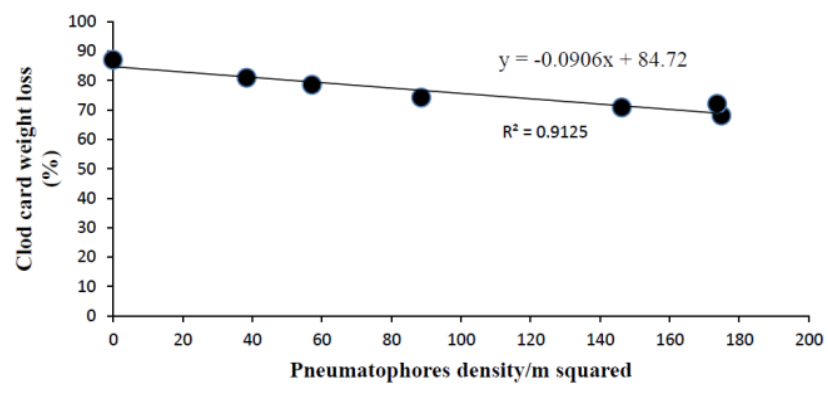

Figure 8. Linear relationship between wave energy against pneumatophore densities in seven transects 


\section{Effect of tree and pneumatophores density on sinking metal disks}

The means for sinking metal disks of different stations were determined, and results compared with tree density/ha and pneumatophores density per $\mathrm{m}^{2}$. The depth of metal disks decreased with an increase in mangrove tree density (Figure 10).

A plot of sinking metal disk against pneumatophores density per $\mathrm{m}^{2}$ showed similar treads with the one plotted against tree density/ha. The depth of metal disks decreased with increased pneumatophores density per $\mathrm{m}^{2}$ (Figure 11).

The regression analysis showed a significant difference in sediment stability against tree density $\left(\mathrm{R}^{2}=61 \%, \mathrm{P}=\right.$ $0.028)$ and basal areas $\left(R^{2}=72.8 \%, p=0.015\right)$ whilst there was no significant difference between sediment stability and pneumatophores density $\left(\mathrm{R}^{2}=47 \%, \mathrm{p}=0.089\right)$.

Sediment accretion rates in six transects showed a net positive gain of $6.3 \pm 2.1 \mathrm{~mm}( \pm \mathrm{SE})$. For 330 days. When extrapolated to annual rates, the transects showed values equal to a mean of-of $5.4 \pm 1.7 \mathrm{~mm}( \pm \mathrm{SE})$. The mean range between the highest and the lowest accreting transect was $12.2 \mathrm{~mm}$ recorded between transect $\mathrm{M}$ and transect $\mathrm{O}$, respectively. Mean sediment accretion rates were highest in transects $\mathrm{K} 13.3 \pm 1.8 \mathrm{~mm}( \pm \mathrm{SE})$, followed by transect $\mathrm{M}$ with $11.5 \pm 2.1(\mathrm{~mm})( \pm \mathrm{SE})$. The lowest mean accretion rates were recorded in transect $\mathrm{P}$ with $1.4 \pm 1.2 \mathrm{~mm}( \pm \mathrm{SE})$ and transect $\mathrm{O}$ with $1.1 \pm 2.8 \mathrm{~mm}( \pm \mathrm{SE})$ within the same period. Sediment accretion rates as shown in (Figure 12).

Regression analysis between mean sediment accretion rates against forest structures showed no significant difference namely; tree density/ ha showed no significant $\left(\mathrm{R}^{2}=7.2 \%, \mathrm{p}=0.608\right)$, basal areas $\left(\mathrm{R}^{2}=8.9 \%, \mathrm{p}=0.566\right)$ and pneumatophores density $/ \mathrm{m}^{2}\left(\mathrm{R}^{2}=11.1 \%, \mathrm{p}=0.415\right) \mathrm{In}$ addition, regression analysis between sediment accretion and wave energy reduction along transects was also not significant $\left(R^{2}=16.7, p=0.489\right)$.

Table 4. Percentage of sediment grain sizes classes and organic matter content in the seven transects (Mean values \pm SE)

\begin{tabular}{lcccc}
\hline Transect & Silt $(\boldsymbol{\%})$ & $\begin{array}{c}\text { Fine sand } \\
(\boldsymbol{\%})\end{array}$ & $\begin{array}{c}\text { Coarse } \\
\text { sand (\%) }\end{array}$ & $\begin{array}{c}\text { Organic } \\
\text { matter }(\%)\end{array}$ \\
\hline $\mathrm{K}$ & $15.0 \pm 5.8$ & $81.7 \pm 4.7$ & $3.3 \pm 1.0$ & $2.1 \pm 0.5$ \\
$\mathrm{~L}$ & $8.8 \pm 1.9$ & $87.6 \pm 0.9$ & $3.5 \pm 0.2$ & $1.4 \pm 0.2$ \\
$\mathrm{M}$ & $15.2 \pm 2.2$ & $79.6 \pm 2.9$ & $5.3 \pm 0.1$ & $1.9 \pm 0.4$ \\
$\mathrm{Q}$ (control) & $3.8 \pm 0.5$ & $93.1 \pm 0.4$ & $3.5 \pm 2.1$ & $0.8 \pm 0.1$ \\
$\mathrm{~N}$ & $5.6 \pm 3.3$ & $81.6 \pm 2.3$ & $12.8 \pm 0.9$ & $1.6 \pm 0.5$ \\
$\mathrm{O}$ & $2.4 \pm 1.4$ & $79.5 \pm 0.8$ & $18.1 \pm 0.5$ & $1.1 \pm 0.3$ \\
$\mathrm{P}$ & $7.0 \pm 2.3$ & $53.4 \pm 2.4$ & $39.7 \pm 0.1$ & $1.2 \pm 0.1$ \\
\hline
\end{tabular}
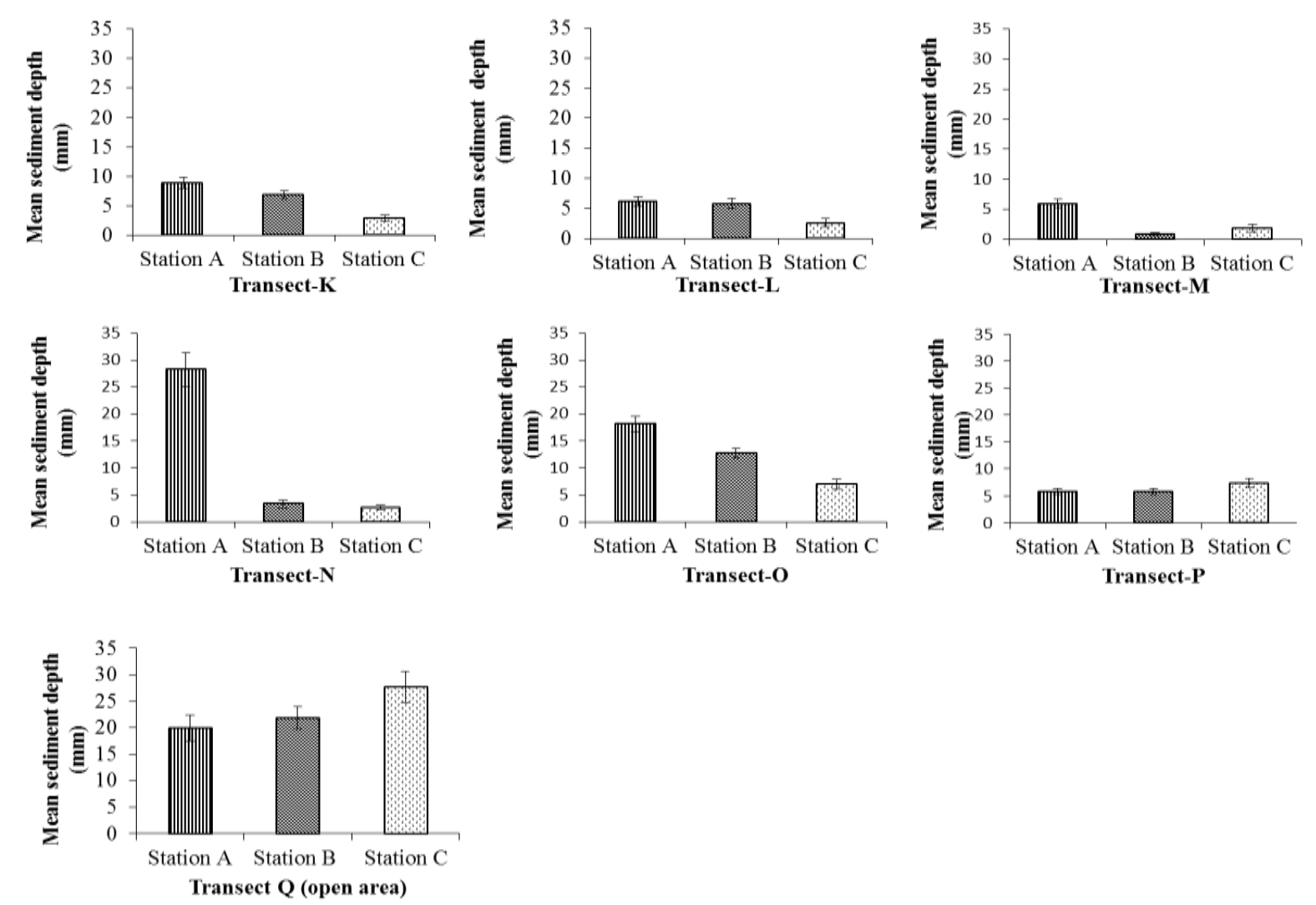

Figure 9. Mean values $( \pm \mathrm{SE})$ of sinking depth of metal discs across station $\mathrm{A}, \mathrm{B}$, and $\mathrm{C}$ along the seven transects 


\section{Discussion}

Provision of natural defenses by mangroves to both human beings and artificial structures along the coast has in the recent past been given a lot of attention following the lessons learned during the $26^{\text {th }}$ December 2004 tsunami in Asia. Many degraded mangrove sites have witnessed accelerated shoreline erosion along the Kenya coast, prompting the government and local communities to put up artificial structures to mitigate the problem with little or no success. However, the restoration attempt guided by scientific findings has provided a lasting and sustainable solution by restocking the degraded sites with suitable species. Increasing the mangrove tree densities has led to stability and functioning of the ecosystem by reducing shoreline erosion and binding of sediment by mangrove forest structures.

\section{Effect of tree and pneumatophores density on the wave energy}

This study demonstrated that wave energy was gradually reduced along $80 \mathrm{~m}$ transects with different tree and pneumatophore $\mathrm{m}$ densities. The data was obtained by comparing dissolution rates of percentage loss of clods card as a proxy to wave energy attenuation across the reforested mangrove forest. The energy reduction by tree stems alone was $7.8 \%$, while pneumatophores' energy reduction was $5 \%$. In total, energy reduction by the two mangrove forest structures was $12.8 \%$. Similar studies in Vinh Quang village and Red River (Song Hong) Vietnam showed that $100 \mathrm{~m}$ of intact mangrove attenuate wave energy up to $45 \%$ (Mazda et al. 1997). This study has proved that mangroves are suitable for coastal vegetation defense to protect shoreline erosion against average wave energy.

The clod cards exposed to water current in the sea were used to express a loss of their weight as a function of water velocity since plaster of Paris objects erodes with the friction with the water. The higher the water velocity, the higher the clod card weight loss. Therefore, it is interesting to compare the relationship between weight losses of the clod cards versus tree and pneumatophores density along transects of the known distance across the mangrove forest. Change in wave energy was plotted as the weight loss of clods (in the y-axis) versus transects with varying pneumatophores density and tree density (in the $\mathrm{x}$-axis). The regression slope was the change in wave energy as tree and pneumatophores density varied among transects.

High wave energy was recorded at $15 \mathrm{~cm}$ above the substrate as demonstrated by high clod card weight loss at this height with a mean of $78.3 \pm 2.3 \%$ (SE) compared to the means of clod cards mounted at $50 \mathrm{~cm}$, which recorded $73.4 \pm 2.4$ in transect that had mangrove trees. A similar power of high wave energy was experienced at $15 \mathrm{~cm}$ above the substrate in the control transect without mangrove cover, registering a mean of $84.0 \pm 2.9 \%$ (SE). In comparison, the energy sampled at $50 \mathrm{~cm}$ was $81.2 \pm$ $2.9 \%$ (SE). However, the capacity to reduce wave energy depends on forest width, tree density, and tree species (Alongi 2009). Mangrove reforestation initiatives at Gazi have seen an increase in tree density of fringing Sonneratia alba from diminishing levels to $448 \pm 212.3$
(SD) at the time of the study. In this study, the site comprised of one species (Sonneratia alba), the semipristine nature of the forest stands coupled with narrow width limited the ability to reduce considerable wave energy contrary to Vinh Quang village along with Red River (Song Hong) Vietnam with pristine fringing mangrove (Mazda et al. 1997).

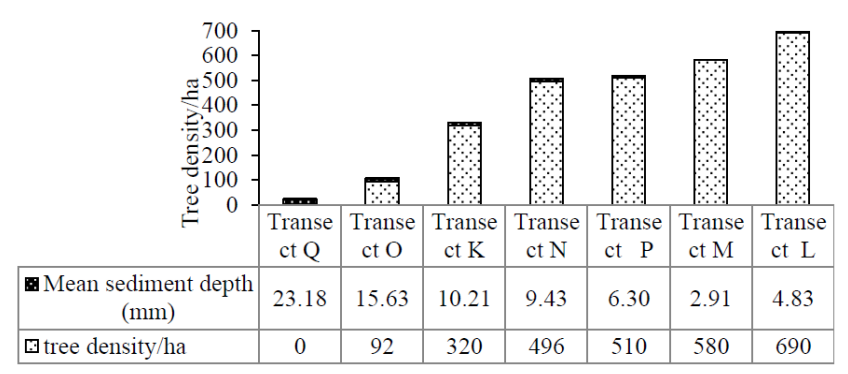

Figure 10. Mean of sinking depth of metal disks against; Tree density/ha across fringing mangrove forest

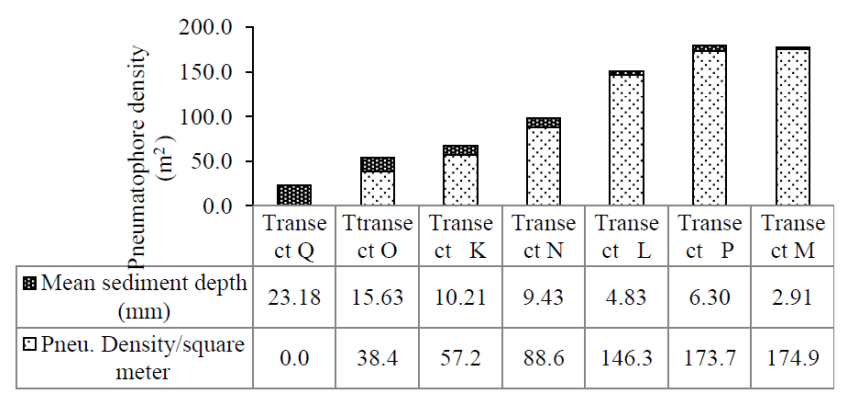

Figure 11. Means of sinking depth of metal disks against pneumatophores density/ $\mathrm{m}^{2}$ across fringing mangrove forest

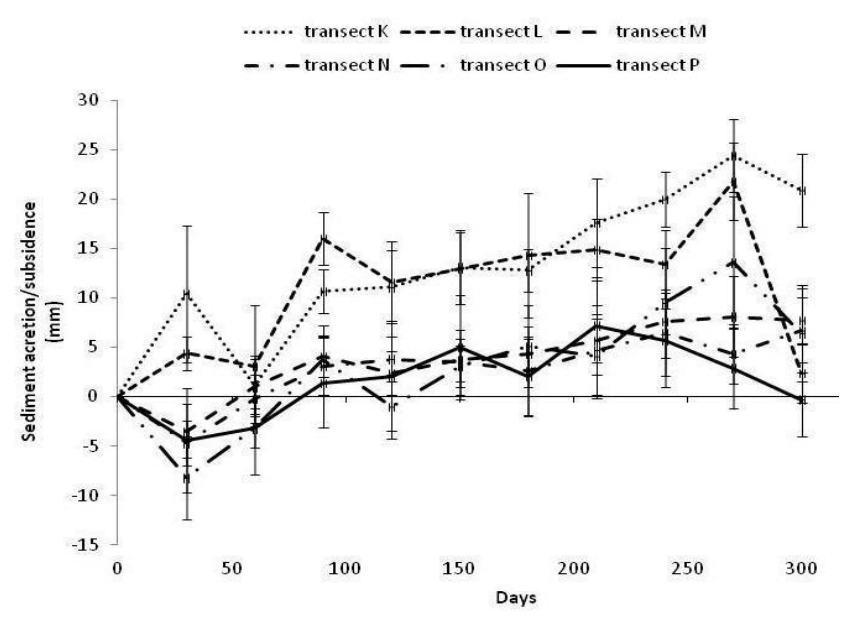

Figure 12. Mean values \pm SE of sediment accretion rate in study area observed for 330 days 
The effect of tree and pneumatophores density on wave energy reduction among different transects demonstrated that increasing tree density enhances the frictional drag by the mangrove forest structures. Pneumatophores of Sonneratia alba taper off upwards, thus reducing their efficiency to maintain high drag force, explaining why more wave energy was experienced at $15 \mathrm{~cm}$ due to pneumatophore influence than energy sampled at $50 \mathrm{~cm}$ due to mangrove tree density (Mazda et al. 1997).

\section{Effect of tree and pneumatophores density on sediment stability and accretion}

Sinking depth of metal disks along transects with different tree densities demonstrated that sediment gains stability with increasing tree and pneumatophores density. The deeper the metal disks sunk in the sediment, the more unstable the sediment was. Therefore, this study showed sinking depth of metal disk reducing gradually with distance from the open areas on the seaward side towards the shoreline as tree and pneumatophores densities varied among transects. The trends in sediment stability demonstrated in this study are similar to those reported in mangroves along the Cairns boardwalk in wet tropical Australia within a fringing Rhizophora sp. (Furukawa and Wolanski, 1996). The sediment transport mechanisms in both sites are dominated by hydrodynamics from waves, and sediment gained stability with increasing distance from the seaward side towards the shore. The sediment particles settled as wave energy-reduced across the mangrove forest, demonstrating the net effect of forest width and tree density on sediment stability as reported elsewhere in the world (Alongi 2009).

Where mangrove tree stems and pneumatophores densities were high, the depth of sinking metal disks in the sediments were less due to reduced wave energy, thus facilitating trapping and holding of sediment. The trapping mechanism resulted from high micro-turbulence created by the flows around the trees structures such as tree stems and pneumatophores (Wolanski 1995; Mazda et al. 1997) during flood tide and settled down at slake water when current flows are low during ebb tide.

The study showed station all A (before the mangroves) in all forested transect having the highest means of sinking depth of metal disks indicating high sediment instability, which decreased with increasing distance across station B through station $\mathrm{C}$. The observation witnessed in this study on sediment stability is accurate of studies done by Balke et al. (2013), who found sediment stability rates increasing with distance from the seaward side towards the shore. In the control transect without mangrove, there was less micro-turbulence due to the absence of mangrove, trees thus making the sinking depths of metal disks increase with distance along with the intertidal complex, an indication of high sediment instability.

The study has demonstrated that degradation of fringing mangrove forests alters sediment stability due to alteration in their physical roles, a condition that has been witnessed elsewhere in the world (Furukawa and Wolanski, 1996). Graphical relationship of sinking depth of metal disks against tree and pneumatophores density showed the mean depth sinking metal disks decreasing with increasing tree stems/ha and pneumatophores density $/ \mathrm{m}^{2}$, highlighting that the replanted fringing forest remains the best option to stabilizing the highly eroded study site at Gazi Bay.

The levels of sinking depth of metal disks improved with reduced exposure to strong wave energy with mangrove forest structures offering a bio-shield by creating frictional drag as reported elsewhere (Furukawa and Wolanski, 1996). In this study, high wave energy was observed from transect without mangrove cover (Control transect) and reduced gradually to reasonably high forested transect. Reducing wave energy levels by mangrove forest structures (tree and pneumatophores density) improves sediment stability along with the inter-tidal complex. Also, transects with high organic matter content and reasonably high silt levels had a low sinking depth of metal disk, indicating improving sediment physio-chemical characteristics (Macnae 1968). This condition makes the mangrove forest a fully functional system (Bosire et al., 2008).

The study showed sediment accretion rates of $5.4 \pm 1.7$ $\mathrm{mm} /$ year $^{-1}$ (SE), which is more or less similar to that reported in Kosrae (FSM) at Yale and Utwe river basin of $4.5 \pm 1.1$ and $9.1 \pm 2.1$ (SE) $\mathrm{mm}$, respectively. Various levels of sediment accretion or subsidence due to the influence of mangrove forest structures such as tree and pneumatophores densities using sediment elevation tables (SETS) method have been reported in many studies worldwide.

The stems and pneumatophores create frictional dragreducing the current flow from wave energy, thereby creating eddies that encourage sedimentation when cohesive particles flocculate mainly due to the presence of clay particles (Furukawa et al. 1997). Our study has shown that reforestation efforts in this site have boosted the regulatory services offered by mangroves by modifying the physical characteristics of the sediment. The phenomena have been observed in transects $\mathrm{M}, \mathrm{K}$, and $\mathrm{L}$, which expressed the highest clay particles, which bind sediment together, thus supporting the sediment accretion. Transect with the smallest clay particles as witnessed at transect $\mathrm{O}$, which had the lowest tree and pneumatophores density, expressed the least mean accretion rates. Thereby, the study shows that by increasing tree stems through reforestation, sediment is less prone to resuspension by waves, thus reducing shoreline erosion compared to other earlier efforts of mitigating shoreline protection through the construction of gabions.

\section{Conclusion}

Using the inexpensive clod card dissolution method to quantify wave energy attenuation as a regulatory service, this study has established baseline data to help monitor and quantitatively estimate the role of mangrove forests in shoreline protection and how this changes with this tree density. Evidence of the study site regaining stability after replanting mangroves is a more sustainable and costeffective method than putting up complex engineering structures. The approach can easily be replicated elsewhere in many sites along the Kenyan coast and western Indian 
Ocean. Mangroves are potentially used as a bio-shield that shall provide other ecosystem benefits such as increased biodiversity aesthetic beauty. They will have potential application in disaster risk reduction in the long term. At the study site in Gazi Bay, mangroves proved to reduce on average $7.8 \%$ of wave energy in transects with trees compared to open areas without trees. In contrast, sediment stability correlated positively with an increase in tree and pneumatophores density as wave energy reduces. Stable sediments have shown accretion rates improve as the density of the forest increases over time through reforestation efforts and the shoreline erosion gradually decreases and resists further coastline changes. The primary challenge in the study was the lack of baseline data and other comparative studies on the use of mangrove forests as bio-shields to provide coastal protection against average wave energy impacts along the Kenya coast and the Western Indian Ocean region.

\section{REFERENCES}

Abuodha PAW, Kairo JG. 2001. Human-induced stresses on mangrove swamps along the Kenyan coast. Hydrobiologia 458 (1): 255-265. DOI: $10.1023 / \mathrm{A}: 1013130916811$.

Alongi DM. 2009. The Energetics of Mangrove Forests. Australian Institute of Marine Science, Townsville, Queensland, Australia.

Balke T, Webb EL, den Elzen E, Galli D, Herman PM, Bouma TJ. 2013 Seedling establishment in a dynamic sedimentary environment: a conceptual framework using mangroves. J Appl Ecol 50 (3): 740-747. DOI: $10.1111 / 1365-2664.12067$

Bell J, Lovelock CE. 2013. Insuring mangrove forests for their role in mitigating coastal erosion and storm-surge : An Australian case study. Wetlands 33 (2): 279-289. DOI: 10.1007/s13157-013-0382-4.

Bosire JO, Dahdouh-guebas F, Kairo JG, Koedam N. 2003. Colonization of non-planted mangrove species into restored mangrove stands in Gazi Bay. Aquat Bot 76 (4): 267-279. DOI: 10.1016/S03043770(03)00054-8.

Bosire JO, Dahdouh-guebas F, Walton M, Crona BI, Lewis RR, Field C, Koedam N. 2008. Functionality of restored mangroves: A review. Aquat Bot 89 (2): 251-259. DOI: 10.1016/j.aquabot.2008.03.010.

Brower JE, Zar JH, Carl N. 1990. Field and Laboratory Techniques for General Ecology. 3rd ed. Wm.C. Brown Publishers, New York.

Cintron G, Schaeffer-Novelli Y. 1984. Methods for studying mangrove structure. The Mangrove Ecosystem: Research Methods. UNESCO, Paris.

Crona BI, Holmgren S, Ronnback P. 2006. Re-establishment of epibiotic communities in reforested mangroves of Gazi Bay, Kenya. Wetlands Ecol 14 (6): 345-360. DOI: 10.1007/s11273-006-9005-7.

Dahdouh-Guebas F, Mathenge C, Koedam N. 2000. Utilization of mangroves wood products around Minda Creek (Kenya) among subsistence and commercial users. Econ Bot 54: 513-527. DOI: 10.1007/BF02866549.

Furukawa K, Wolanski E, Mueller H. 1997. Currents and sediment transport in mangrove. Estuar Coast Shelf Sci 44 (3): 301-310. DOI: 10.1006/ecss.1996.0120.

Furukawa K, Wolanski E. 1996. Sedimentation in mangrove forest. Mangroves Salt Marshes 1 (1): 3-10. DOI 10.1023/A:1025973426404.

Gilman EL, Ellison J, Duke NC, Field C. 2008. Threats to mangroves from climate change and adaptation options : A review. Aquat Bot 89 (2): 237-250. DOI: 10.1016/j.aquabot.2007.12.009.
Giri C, Ochieng E, Tieszen LL, Zhu Z, Singh A, Loveland T, Masek J, Duke N. 2010. Status and distribution of mangrove forests of the world using earth. Glob Ecol Biogeogr 20 (1): 236-255. DOI: 10.1111/j.1466-8238.2010.00584.x.

GOK. 2010. National Climate Change Response Strategy. Ministry of Environment and Mineral Resources Nairobi, Kenya.

Hamsa J. 2013. Mangroves and Livelihood: An Assessment of Livelihood Project in Mangroves Ecosystem along The Kenyan Coast. [Thesis]. Vrije University Brussels, Belgium.

Kairo JG, Bosire J, Koedam N. 2001. Restoration and management of mangrove systems - a lesson for and from the East African region. South Afr J Bot 67 (3): 383-389. DOI: 10.1016/S02546299(15)31153-4

Kairo JG, Lang JKS, Dahdouh-guebas F, Bosire J, Karachi M. 2008. Structural development and productivity of replanted mangrove plantations in Kenya. For Ecol Manag 255 (7): 2670-2677. DOI: 10.1016/j.foreco.2008.01.031.

Kairo JG, Wanjiru C, Ochiewo J. 2009. Net pay: Economic analysis of a replanted mangrove plantation in Kenya. J Sustain For 28 (3-5): 395414. DOI: 10.1080/10549810902791523.

Kairo JG. 1995. Artificial Regeneration and Sustainable Yield Management of Mangrove Forests at Gazi Bay. [Thesis]. Botany Department, University of Nairobi, Nairobi, Kenya.

Keryn B, Gedan M, Kirwan L, Eric W, Edward BB. 2011. The present and future roles of coastal wetland vegetation in protecting shorelines: answering recent challenges to the paradigm. Clim Change 106 (1): 7 29. DOI: $10.1007 / \mathrm{s} 10584-010-0003-7$

Kirui KB, Kairo JG, Bosire J, Viergever KM, Rudra S, Huxham M, Briers RA. 2012. Ocean coastal management mapping of mangrove forest land cover change along the Kenya coastline using Landsat imagery. Ocean Coast Manag 30: 1-6. DOI: 10.1016/j.ocecoaman.2011.12.004.

Kitheka JU, Ongwenyi GS, Mavuti KM. 2003. Fluxes and exchange of suspended sediment in tidal inlets draining a degraded mangrove forest in Kenya. Estuar Coast Shelf Sci 56 (3-4): 655-667. DOI: 10.1016/S0272-7714(02)00217-2.

Krauss W, Mckee KL, Lovelock CE, Cahoon DR, Saintilan N, Reef R, Chen L. 2013. How mangrove forests adjust to rising sea level. New Phytol 202 (1): 19-34. DOI: 10.1111/nph.12605.

Macnae W. 1968. A General account of the flora and fauna of mangrove swamps and forests in the Indo-West-Pacific region. In: Russel FS, Yonge $M$ (eds) Advances in Marine Biology 6: 74-165. DOI: 10.1016/S0065-2881(08)60438-1.

Mazda Y, Wolanski E, King B, Sase A, Ohtsuka D, Magi M. 1997. Drag force due to vegetation in mangrove swamps. Mangroves Salt Marshes 1 (3): 193-199. DOI: 10.1023/A:1009949411068.

Mckee KL, Cahoon DR, Feller IC. 2007. Caribbean mangroves adjust to rising sea levels through biotic controls on change in soil elevation. Glob Ecol Biogeogr 16 (5): 545-556. DOI: 10.1111/j.14668238.2007.00317.x.

Neukermans G, Kairo JG, Koedam N, Neukermans G, Roosevelt AFD. 2008. Mangrove species and stand mapping in Gazi Bay (Kenya) using Quickbird Satellite Imagery. Spatial Sci 53 (1): 75-86. DOI: 10.1080/14498596.2008.9635137.

Skove MW, Vannini M, Shunula JP, Hartnoll RG, Cannicci S. 2002. Quantifying the density of mangrove crabs: Ocypodidae and Grapsidae. Mar Biol 141 (4): 725-732. DOI: 10.1007/s00227-0020867-9.

Spalding M, Kainuma M, Collins L. 2010. World Atlas of Mangroves. Earthscan, London, UK. DOI: 10.4324/9781849776608.

Valiela I, Jennifer BL, Joanna YK. 2001. Mangrove forests: one of the world's s threatened major tropical environments. Bioscience 51 (10): $807-815$. DOI:

$10.1641 / 0006$ 3568(2001)051[0807:MFOOTW]2.0.CO;2.

Williams N. 2005. Tsunami insight to mangrove value. Curr Biol 15 (3): R73. DOI: 10.1016/j.cub.2005.01.015.

Wolanski E. 1995. Transport of sediment in mangrove swamps. Hydrobiologia 295: 31-42. DOI: 10.1007/978-94-011-0289-6_5. 